\title{
Death of the book greatly excggervied
}

by Phillip H. Young

\section{Dateline: Indianapolis, Indiana Location: Estate auction}

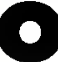
n a hot and humid August afternoon the press of sweaty humanity ebbs and flows around and through a decaying two-story house in a run-down neighborhood of Indianapolis. The amplified sing-song cadences of the auctioneers rise above the buzz of hundreds of buyers who have answered the summons of a classified ad proclaiming the no-reserves sale of an untouched estate which includes hundreds of boxes of household items, many pieces of Victorian furniture, over 300 collectible dolls-and, last but not least, thousands of books. As three auction rings operate simultaneously, the crowd divides itself into bargain hunters and furniture buyers, doll collectors, and book aficionados. As the afternoon wears on, it is my observation that, to paraphrase Mark Twain, reports of the imminent demise of the book are greatly exaggerated, at least for the "real world" outside the library.

The backyard of the ramshackle house is literally covered with rows and rows of cardboard boxes filled with old books, and on at least a dozen tables the auction staff has selected out volumes deemed newer and more desirable. The midday sun of late summer beats down, but dozens of eager people elbow their way to get to the boxes where they dig through the dirty, leatherbound tomes searching for a prize. Before long everyone is comparing the amount of grime on their hands as they bring forward to the auction table selected volumes requested for sale. The auctioneer is singing out prices, amounts bid, and amounts wanted while observers crane their necks to peruse each tome as the assistants hold them up in the air.
The scene is remarkable to a librarian steeped in the pursuit of the latest information technology-here are hundreds of average, everyday people actually pawing their way through a sweaty crowd for the sole purpose of acquiring books! No professor's assignment or BI class has forced them to come. No academic "publish or perish" mandate lies behind their presence. These people are here simply out of an interest in books for their own sake. Granted, some are book dealers or antique mongers who are hoping to pick up a tome to sell for profit in their shops. But most of the people are just book lovers buying for their personal pleasure. Some of the more popular books are on crafts or sewing, but novels and nonfiction and even old government documents are selling briskly.

The auctioneers in their feigned enthusiasm unabashedly mutilate titles and topics, announcing a set of books called Waverly Novels by Mr. Waverly and a copy of Mein Kampf in English as probably being a copy from the original printing! But the crowd doesn't care, watching intently for every opportunity to buy at a bargain price or to fight it out in a bidding war over a special title.

I watch with pleased amusement as refugees from the doll sale wander into the back yard and exclaim, "Oh, look. Here are the books!" as they happily join the crowd. It is clear to me that these book lovers are not wrestling with the ever-increasing bite taken out of book budgets by CD-ROMs' laserdisks and periodicals subscriptions. They have not read the reports of an imminent paperless society and the demise of the book in favor of online, digital information retrieval. They have not retuned their bibliographic focus from acquisition to access and their goals from learning facilitation and knowledge accumulation to in- 
formation retrieval. They are not even worried that the books they are buying may be out of date, containing "bad" information. I am aware of my own surprise at seeing people scoop up old periodicals, reference books, damaged materials, antique editions, etc., that we routinely throw away at the library.

A large children's book illustrated by Maxfield Parrish has caught the attention of the crowd; the bidding is intense, going higher and higher until the book - which is in pretty good condition but still somewhat worn-sells for $\$ 650$. Some of us from the professional book world shake our heads in disbelief, but the book buyers seem unperturbed as the sale moves right along to 19 th century bound volumes of The Youth's Companion, editions of James Whitcomb Riley (obviously a favorite for Hoosiers), boxes of old Life magazines, and then to an old art textbook. A handbook on raising flowers in your garden is sold next to a first edition of Mark Twain (a disintegrating leather tome with detached covers repaired with old, yellowing cellophane tape), and a coffee-table book on gems of the world next to a numbered, limited edition set of Dickens' works. This mad gamble has brought out a common theme in the disparate denizens of this backyard drama: all these people love books!

By the end of the day my face is sunburned and my feet tired, but my own little stack of treasures has grown tall. Through an amazing distribution process the lifelong book collection of someone we will never know has been parcelled out to a hoard of people who may

\section{bere are bundreds of aver- age, everyday people actually pawing their way through a sweaty crowd for the sole purpose of acquiring books!}

never come together again but who will return home with books to be read, cherished as works of art, or marked up in price and resold to other bibliophiles. Somehow I can't see these people forsaking their books for computer screens or spending all their spare hours staring at reruns of old movies on television. The good news is that there still is a "real world" where books and literacy are not yet dead.

\section{Letters}

\section{Are standards appropriate?}

To the Editor:

The revised Standards for Faculty Status (May 1992) seem to me to make perfect sense but for their apparent assumption that the status of teaching faculties (referred to as if appropriate to them, although that may be doubted) is everywhere and automatically appropriate to academic librarians. Surely it is strange to set forth as standards whatever working conditions apply to larger populations laboring alongside those persons whom the standards in question are intended to benefit.

I hope that librarians contemplating employment in colleges and universities that have accepted the nine standards will scrutinize every aspect of employment to which the standards refer (especially tenure and promotion) and then decide whether conditions at particular institutions are ones they not only can endure but can, as it were, joyfully embrace. (But why are we not setting forth our own standardsstandards applicable to all academic librarians, indeed, to all members of the profession regardless of the kinds of libraries that employ them? A related question: Is academic librarianship essentially a subset of library service or a subset of higher education? If the latter, ACRL should consider leaving ALA and emigrating to what? - the AAUP? - even if to enjoy only marginal status there.)-Robert $M$. Pierson, cataloger, The Santa Fe Indian Scbool, New Mexico

\section{Kudos for Washington Hotline}

To the Editor:

I was pleased to see "Washington Hotline" focus on telecommunications issues (April 1992). Librarians have a lot of homework to do to keep up with these complex and important issues.Mark Scott, Massacbusetts Institute of Technology

(C\&RL News welcomes your signed, typed comment on recent content in our pages or on matters of interest to the academic or research library profession. Send to: The Editor, C\&RL News, $50 \mathrm{E}$. Huron St., Chicago, IL 60611-2795; fax: (312) 280 7663; bitnet: U38398@UЛСVM.bitnet 